\title{
Antimicrobial Effects of Silver(I) and Bismuth(III) Complexes with Secnidazole-Derived Schiff Base Ligands: the Role of the Nitro Group Reduction
}

\author{
Ana P. A. Oliveira, ${ }^{a}$ João F. G. Ferreira, ${ }^{b}$ Luiz M. Farias, ${ }^{b}$ Paula P. Magalhães, ${ }^{b}$ \\ Leticia R. Teixeira ${ }^{a}$ and Heloisa Beraldo ${ }^{\circledR} * a$ \\ ${ }^{a}$ Departamento de Química, Universidade Federal de Minas Gerais, \\ 31270-901 Belo Horizonte-MG, Brazil \\ ${ }^{b}$ Departamento de Microbiologia, Universidade Federal de Minas Gerais, \\ 31270-901 Belo Horizonte-MG, Brazil
}

$\left[\mathrm{Ag}(\mathrm{HL}) \mathrm{NO}_{3}\right]$ complexes (1-4) were obtained with $(E)-N^{\prime}$-(1-(2-methyl-5-nitro-1H-imidazol1-yl)propan-2-ylidene)acetohydrazide (HL1); $(E)-N^{\prime}$-(1-(2-methyl-5-nitro-1H-imidazol-1-yl) propan-2-ylidene)benzohydrazide (HL2); (E)-2-(1-(2-methyl-5-nitro-1H-imidazol-1-yl)propan2-ylidene)hydrazinecarbothioamide (HL3) and $(E)$ - $N$-methyl-2-(1-(2-methyl-5-nitro-1 H-imidazol1-yl)propan-2-ylidene)hydrazinecarbothioamide (HL4) secnidazole-derived Schiff bases. In addition, complexes $\left[\mathrm{Bi}(\mathrm{HL} 3) \mathrm{Cl}_{3}\right](\mathbf{5})$ and $\left[\mathrm{Bi}(\mathrm{HL} 4) \mathrm{Cl}_{3}\right](\mathbf{6})$ were also prepared. The silver(I) complexes (1-4) showed antifungal activity against Candida fungal strains while the uncomplexed ligands and the bismuth(III) complexes (5-6) were inactive, suggesting that the antifungal effects are probably due to the presence of silver. Although the Schiff base ligands and complexes (1-6) revealed to be inactive against Gram-positive and Gram-negative aerobic bacteria, all compounds exhibited potent antimicrobial effects against several anaerobic bacterial strains, indicating that their mode of action probably involves anaerobic bio reduction of the nitro group, with formation of metabolites which are toxic to the microorganisms. Electrochemistry studies showed that bio reduction of the nitro group is favored in complexes (1-6) in comparison to the free ligands, which might, at least in part, explain their increased antimicrobial effects.

Keywords: secnidazole Schiff bases, silver(I) complexes, bismuth(III) complexes, antifungal, antibacterial, anaerobic bacteria

\section{Introduction}

Thiosemicarbazones and hydrazones are compounds possessing a wide range of pharmacological applications as antitumor, antiviral, antiparasitic, antifungal and antibacterial agents. ${ }^{1,2}$ Their metal complexes also exhibit antineoplastic ${ }^{3,4}$ and antimicrobial ${ }^{5}$ activities, among others.

Silver compounds are well known for their applications as antimicrobial agents. Silver nitrate and silver sulphadiazine are employed in balms to prevent wounds and burns infections. ${ }^{6}$ The literature reports that a series of silver(I) complexes with 1-(2-hydroxyethyl)-2-methyl5-nitro- $1 \mathrm{H}$-imidazole (metronidazole) exhibit antibacterial and antifungal properties. ${ }^{7}$ In addition, silver(I) complexes with 4(5)-(hydroxymethyl)imidazole show antibacterial activity against Gram-positive bacteria. ${ }^{8}$

*e-mail: hberaldo@ufmg.br, heloisaberaldoufmg@gmail.com
Bismuth compounds also have been shown to exhibit numerous antimicrobial activities. ${ }^{9}$ Bismuth containing therapies are recommended as the first-line treatment of Helicobacter pylori infection in several countries. ${ }^{10}$ Bismuth complexes with a variety of organic ligands proved to show antimicrobial affects. ${ }^{9,11}$

Secnidazole (1-(2-hydroxypropyl)-2-methyl5 -nitroimidazole), an orally available antimicrobial drug, is a recent generation 5-nitroimidazole derivative. Secnidazole and other 5-nitroimidazole antimicrobial agents show bactericidal activity against susceptible pathogens by diffusing into the organism, where the inactive parent prodrug compound undergoes reduction of the nitro group to cytotoxic metabolites, leading to DNA damage, disruption of bacterial protein synthesis and replication, and ultimately, cell death. ${ }^{12,13}$

In a previous work ${ }^{14}$ we reported the syntheses of thiosemicarbazones and hydrazones containing 
the antimicrobial secnidazole pharmacophoric group functionalized with the Schiff base chelating moiety. These compounds and their copper(II) complexes proved to present antibacterial activity against anaerobic bacterial strains.

Aiming to further understand the effects of metal complexation on the antimicrobial activities of nitroimidazolederived compounds, in the present work $\left[\mathrm{Ag}(\mathrm{HL}) \mathrm{NO}_{3}\right]$ complexes (1-4) were obtained with $(E)-N^{\prime}$-(1-(2-methyl5-nitro- $1 H$-imidazol-1-yl)propan-2-ylidene) acetohydrazide (HL1), (E)-N'-(1-(2-methyl-5-nitro$1 H$-imidazol-1-yl)propan-2-ylidene)benzohydrazide (HL2), (E)-2-(1-(2-methyl-5-nitro-1H-imidazol-1-yl) propan-2-ylidene)hydrazinecarbothioamide (HL3) and (E)- $N$-methyl-2-(1-(2-methyl-5-nitro-1H-imidazol-1-yl) propan-2-ylidene)hydrazinecarbothioamide (HL4), as well as complexes $\left[\mathrm{Bi}(\mathrm{HL} 3) \mathrm{Cl}_{3}\right](\mathbf{5})$ and $\left[\mathrm{Bi}(\mathrm{HL} 4) \mathrm{Cl}_{3}\right](\mathbf{6})$ (see Figure 1).

Taking into consideration that 5-nitroimidazoles are prodrugs that require intracellular bioactivation of the nitro group in order to exert their biological action, ${ }^{13}$ the electrochemical behavior of the compounds under study was investigated along with their antimicrobial effects against yeast and against aerobic and anaerobic bacterial strains.

\section{Experimental}

\section{Materials and measurements}

All common chemicals were purchased from Aldrich and were used without further purification. Partial elemental analyses were performed on a PerkinElmer CHN 2400 analyzer. A Digimed model DM3 conductivity bridge was employed for molar conductivity measurements. Infrared spectra were recorded on a PerkinElmer FTIR Spectrum GX spectrometer using $\mathrm{KBr}$ pellets $\left(4000-400 \mathrm{~cm}^{-1}\right)$. Nuclear magnetic resonance (NMR) spectra were obtained with a Bruker DPX-400 Advance (400 MHz) spectrometer using dimethyl sulfoxide (DMSO- $d_{6}$ ) as the solvent and TMS (tetramethylsilane) as internal reference. Cyclic voltammetry experiments were carried out at room temperature with a conventional three-electrode cell (with volumetric capacity of $10 \mathrm{~mL}$ ) in an Autolab type PGSTAT30 equipment, using the Nova 2.1.3 software. The working electrode was a Metrohm glassy carbon electrode, the auxiliary electrode was a platinum wire and $\mathrm{Ag} / \mathrm{AgCl}, \mathrm{Cl}^{-}(3.0 \mathrm{M})$ was used as the reference electrode. The glassy carbon electrode was previously finepolished with $0.3 \mu \mathrm{m}$ alumina slurry on a polishing felt during $5 \mathrm{~min}$. Solutions for analysis were prepared in spectroscopic dimethylformamide (DMF) containing $1 \mathrm{mM}$ of analyte and $0.1 \mathrm{M}$ of tetrabutylammonium perchlorate (TBAP) as supporting electrolyte. Before recording the voltammograms, the test solution was thoroughly purged with high purity nitrogen gas to remove any traces of dissolved oxygen. Cyclic voltammograms were recorded in the 1.50 to $-1.50 \mathrm{~V}$ potential range using $250 \mathrm{mV} \mathrm{s}^{-1}$ scan rate.

\section{Chemistry}

Syntheses of secnidazole-derived hydrazones and thiosemicarbazones

The secnidazole-derived hydrazones and thiosemicarbazones were prepared as previously reported. ${ }^{14}$

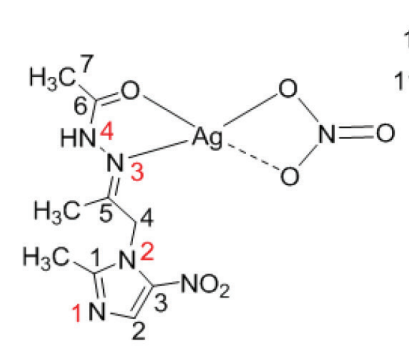

(1)

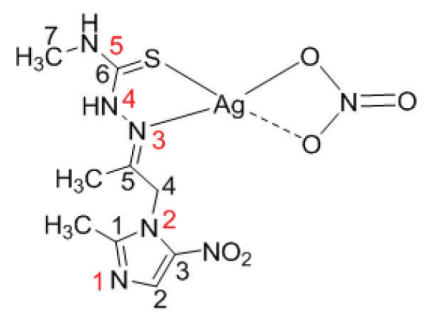

(4)

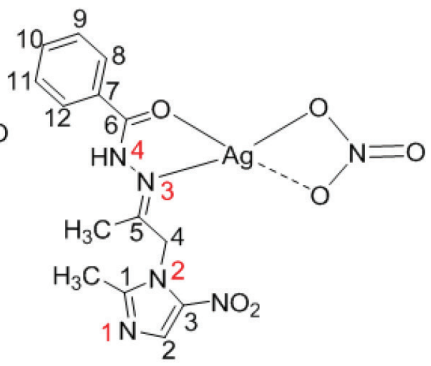

(2)

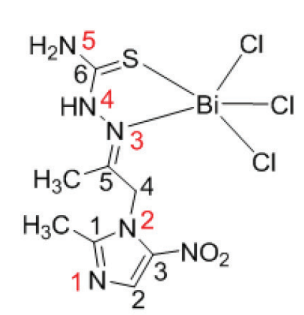

(5)

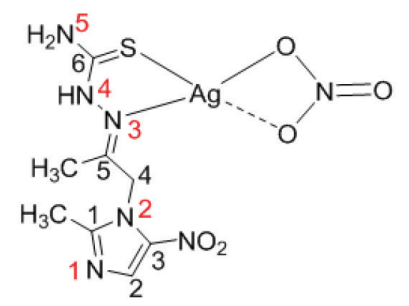

(3)

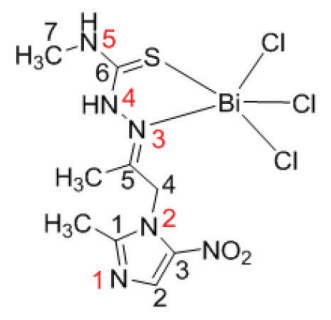

(6)

Figure 1. Structural representations of complexes (1-6). 
Syntheses of silver(I) complexes (1-4)

The silver(I) complexes were obtained by stirring a methanol solution $(10 \mathrm{~mL})$ of the desired ligand $(1.0 \mathrm{mmol})$ with an aqueous solution of $\mathrm{AgNO}_{3}(3 \mathrm{~mL})$ added dropwise in equimolar amount. The reaction mixture was kept under stirring in the dark at room temperature for $24 \mathrm{~h}$. The obtained solids were vacuum filtered, washed with methanol followed by diethyl ether and then dried under reduced pressure.

[(E)-N'-(1-(2-Methyl-5-nitro-1 H-imidazol-1-yl)propan2-ylidene)acetohydrazidenitrate]silver(I) $\left[\mathrm{Ag}(\mathrm{HL} 1) \mathrm{NO}_{3}\right]$ (1)

Yellow solid; anal. calc. for $\mathrm{C}_{9} \mathrm{H}_{13} \mathrm{AgN}_{6} \mathrm{O}_{6}(\mathrm{FW}$ : $409.10 \mathrm{~g} \mathrm{~mol}^{-1}$ ): C, 26.42; H, 3.20; N, 20.54; found: C, 26.44; H, 3.15; N, 20.38; decomposition at $135^{\circ} \mathrm{C}$; molar conductivity $\left(1.0 \times 10^{-3} \mathrm{~mol} \mathrm{~L}^{-1} \mathrm{DMSO}\right) 39.86 \mathrm{~cm}^{2} \Omega^{-1} \mathrm{~mol}^{-1}$; IR (KBr) v / cm 3300 ( $v$ N4-H), 1678 ( $v$ C=O), 1554 ( $v$ $\mathrm{C} 5=\mathrm{N}), 1488 / 1380\left(\mathrm{v}_{\text {ass }} / \mathrm{v}_{\mathrm{s}} \mathrm{NO}_{2}\right), 1380\left(\mathrm{v} \mathrm{NO}_{3}\right) ;{ }^{1} \mathrm{H} \mathrm{NMR}$ (400.13 MHz, DMSO- $d_{6}$ ) $\delta /$ ppm 10.38 (s, 1H, N4H), 8.08 (s, 1H, H2), 5.12 (s, 2H, H4), 2.42 (s, 3H, $\mathrm{C} 1 C H_{3}$ ), $1.94\left(\mathrm{~s}, 3 \mathrm{H}, \mathrm{C} \mathrm{CH}_{3}\right), 1.64(\mathrm{~s}, 3 \mathrm{H}, \mathrm{H} 7) ;{ }^{13} \mathrm{C}\left\{{ }^{1} \mathrm{H}\right\} \mathrm{NMR}$ (100.61 MHz, DMSO- $d_{6}$ ) $\delta$ / ppm 172.2 (C6), 151.9 (C1), 144.8 (C5), 138.6 (C3), 132.0 (C2), 50.2 (C4), 20.0 (C7), $\left.14.4\left(\mathrm{C}_{5} \underline{\mathrm{CH}}_{3}\right)\right), 13.9\left(\mathrm{C}_{1} \underline{\mathrm{CH}}_{3}\right)$; yield $61 \%$.

[(E)-N'-(1-(2-Methyl-5-nitro-1 H-imidazol-1-yl)propan2-ylidene)benzohydrazidenitate]silver(I) $\left[\mathrm{Ag}(\mathrm{HL2}) \mathrm{NO}_{3}\right]$ (2)

Yellow solid; anal. calc. for $\mathrm{C}_{14} \mathrm{H}_{15} \mathrm{AgN}_{6} \mathrm{O}_{6}(\mathrm{FW}$ : $471.17 \mathrm{~g} \mathrm{~mol}^{-1}$ ): $\mathrm{C}, 35.69 ; \mathrm{H}, 3.21$; N, 17.84; found: $\mathrm{C}$, 35.38; H, 3.09; N, 17.72; melting point: $184.1-184.3{ }^{\circ} \mathrm{C}$; molar conductivity $\left(1.0 \times 10^{-3} \mathrm{~mol} \mathrm{~L}^{-1} \mathrm{DMSO}\right)$ $38.10 \mathrm{~cm}^{2} \Omega^{-1} \mathrm{~mol}^{-1}$; IR (KBr) $v / \mathrm{cm}^{-1} 3144$ ( $\left.\mathrm{v} \mathrm{N} 4-\mathrm{H}\right)$, $1654(v \mathrm{C}=\mathrm{O}), 1552(\mathrm{v} \mathrm{C} 5=\mathrm{N}), 1486 / 1388\left(v_{\text {ass }} / v_{\mathrm{s}} \mathrm{NO}_{2}\right)$, $1388\left(\mathrm{v} \mathrm{NO}_{3}\right) ;{ }^{1} \mathrm{H}$ NMR $\left(400.13 \mathrm{MHz}, \mathrm{DMSO}-d_{6}\right) \delta / \mathrm{ppm}$ 10.72 (s, 1H, N4H), 8.11 (s, 1H, H2), 7.79 (s, 2H, H8, H12), 7.58-7.17 (m, 3H, H9, H10, H11), 5.27 (s, 2H, H4), $2.50\left(\mathrm{~s}, 3 \mathrm{H}, \mathrm{C} 1 \mathrm{CH}_{3}\right), 2.06\left(\mathrm{~s}, 3 \mathrm{H}, \mathrm{C} \mathrm{CH}_{3}\right) ;{ }^{13} \mathrm{C}\left\{{ }^{1} \mathrm{H}\right\} \mathrm{NMR}$ (100.61 MHz, DMSO- $d_{6}$ ) $\delta /$ ppm 163.1 (C6), 156.4 (C1), 152.1 (C5), 138.4 (C3), 133.6 (C7), 132.1 (C2), 131.4 (C10), 128.2 (C9, C11), 127.7 (C8, C12), 50.4 (C4), 15.7 $\left.\left(\mathrm{C}^{\mathrm{C}} \mathrm{CH}_{3}\right)\right), 14.0\left(\mathrm{C}^{\mathrm{C}} \mathrm{H}_{3}\right)$; yield $78 \%$.

[(E)-2-(1-(2-Methyl-5-nitro-1H-imidazol-1-yl)propan2-ylidene)hydrazinecarbothioamidenitrate]silver(I) $\left[\mathrm{Ag}(\mathrm{HL} 3) \mathrm{NO}_{3}\right](3)$

Yellow solid; anal. calc. for $\mathrm{C}_{8} \mathrm{H}_{12} \mathrm{AgN}_{7} \mathrm{O}_{5} \mathrm{~S}$ (FW: $\left.426.16 \mathrm{~g} \mathrm{~mol}^{-1}\right)$ : C, 22.55; H, 2.84; N, 23.01; found: C, $22.71 ; \mathrm{H}, 2,79 ; \mathrm{N}, 23.27$; decomposition at $125^{\circ} \mathrm{C}$; molar conductivity $\left(1.0 \times 10^{-3} \mathrm{~mol} \mathrm{~L}^{-1} \mathrm{DMSO}\right) 29.30 \mathrm{~cm}^{2} \Omega^{-1} \mathrm{~mol}^{-1}$; IR (KBr) v / $\mathrm{cm}^{-1} 3176(v$ N4-H), $1530(v$ C5=N), 1466/1377 $\left(v_{\text {ass }} / v_{\mathrm{s}} \mathrm{NO}_{2}\right), 794(\mathrm{v} \mathrm{C}=\mathrm{S}), 1384\left(\mathrm{v} \mathrm{NO}_{3}\right) ;{ }^{1} \mathrm{H} \mathrm{NMR}$ $\left(400.13 \mathrm{MHz}, \mathrm{DMSO}-d_{6}\right) \delta$ / ppm 10.87 (s, 1H, N4H), 8.82 (s, 1H, N5H), 8.08 (s, 1H, H2), 7.32 (s, 1H, N5H), 5.19 (s, 2H, H4), 2.41 (s, 3H, C1CH $\mathrm{CH}_{3}, 2.05$ (s, 3H, $\mathrm{C}^{2} \mathrm{CH}_{3}$ ); ${ }^{13} \mathrm{C}\left\{{ }^{1} \mathrm{H}\right\}$ NMR (100.61 MHz, DMSO- $\left.d_{6}\right) \delta / \mathrm{ppm} 174.4$ (C6), 153.8 (C1), 151.9 (C5), 138.4 (C3), 132.7 (C2), 50.2 (C4), $\left.15.6\left(\mathrm{C}^{2} \underline{\mathrm{CH}}_{3}\right)\right), 13.9\left(\mathrm{C}^{\mathrm{C}} \underline{\mathrm{H}}_{3}\right)$; yield $89 \%$.

(E)-N-Methyl-2-(1-(2-methyl-5-nitro-1 H-imidazol-1-yl) propan-2-ylidene)hydrazinecarbothioamidenitrate]silver(I) $\left[\mathrm{Ag}(\mathrm{HL} 4) \mathrm{NO}_{3}\right](4)$

Brown solid; anal. calc. for $\mathrm{C}_{9} \mathrm{H}_{14} \mathrm{AgN}_{7} \mathrm{O}_{5} \mathrm{~S}$ (FW: 440.18 $\left.\mathrm{g} \mathrm{mol}^{-1}\right)$ : C, 24.56; H, 3.21; N, 22.27; found: C, 23.97; H, 3,17; N, 21.22; melting point: $190.0-191.0{ }^{\circ} \mathrm{C}$; molar conductivity $\left(1.0 \times 10^{-3} \mathrm{~mol} \mathrm{~L}^{-1} \mathrm{DMSO}\right) 33.70 \mathrm{~cm}^{2} \Omega^{-1} \mathrm{~mol}^{-1}$; IR (KBr) $v / \mathrm{cm}^{-1} 3262$ ( $v$ N4-H), $1560(v$ C5=N), 1486/1384 $\left(v_{\text {ass }} / \mathrm{v}_{\mathrm{s}} \mathrm{NO}_{2}\right), 788(\mathrm{v} \mathrm{C}=\mathrm{S}), 1384\left(\mathrm{v} \mathrm{NO}_{3}\right) ;{ }^{1} \mathrm{H} \mathrm{NMR}$ $\left(400.13 \mathrm{MHz}, \mathrm{DMSO}-d_{6}\right) \delta / \mathrm{ppm} 10.45$ (s, 1H, N4H], 8.15 (s, 1H, N5H], 8.10 (s, 1H, H2], 5.19 (s, 2H, H4], 3.02 (d, 3H, $\mathrm{H} 7, J 4.50 \mathrm{~Hz}$, 2.45 (s, 3H, C1CH ), 2.02 (s, 3H, $\mathrm{C}^{2} \mathrm{CH}_{3}$ ); ${ }^{13} \mathrm{C}\left\{{ }^{1} \mathrm{H}\right\}$ NMR (100.61 MHz, DMSO- $\left.d_{6}\right) \delta / \mathrm{ppm} 174.3$ (C6), 153.3 (C1), 152.0 (C5), 138.4 (C3), 132.7 (C2), 50.4 (C4), $31.7(\mathrm{C} 7), 15.4\left(\mathrm{C} 5 \underline{C H}_{3}\right), 14.0\left(\mathrm{C}^{\mathrm{C}} \mathrm{H}_{3}\right)$; yield $68 \%$.

\section{Syntheses of bismuth(III) complexes (5-6)}

The bismuth(III) complexes were obtained by mixing equimolar amounts $(0.5 \mathrm{mmol})$ of the desired ligand with $\mathrm{BiCl}_{3}$ in methanol. The reaction mixture was kept under reflux for $24 \mathrm{~h}$. The obtained solids were vacuum filtered, washed with methanol followed by diethyl ether and then dried under reduced pressure. HL1 and HL2 did not react with $\mathrm{BiCl}_{3}$ under the experimental conditions.

[(E)-2-(1-(2-Methyl-5-nitro-1 H-imidazol-1-yl)propan2-ylidene)hydrazinecarbothioamidetrichloro]bismuth(III) [Bi(HL3) $\left.\mathrm{Cl}_{3}\right](5)$

Yellow solid; anal. calc. for $\mathrm{C}_{8} \mathrm{H}_{12} \mathrm{BiCl}_{3} \mathrm{~N}_{6} \mathrm{O}_{2} \mathrm{~S}$ (FW: $571.62 \mathrm{~g} \mathrm{~mol}^{-1}$ ): C, 16.81; H, 2.12; N, 14.70; found: C, 16.88; H, 2.19; N, 14.40; melting point: decomposition at $153.0^{\circ} \mathrm{C}$; molar conductivity $\left(1.0 \times 10^{-3} \mathrm{~mol} \mathrm{~L}^{-1} \mathrm{DMSO}\right)$ $10.03 \mathrm{~cm}^{2} \Omega^{-1} \mathrm{~mol}^{-1}$; IR (KBr) $v / \mathrm{cm}^{-1} 3258$ ( $\left.\mathrm{v} \mathrm{N} 4-\mathrm{H}\right)$, $742(v \mathrm{C}=\mathrm{S}), 1524(\mathrm{v} \mathrm{C} 5=\mathrm{N}), 1430 / 1368\left(v_{\text {ass }} / \mathrm{v}_{\mathrm{s}} \mathrm{NO}_{2}\right)$; ${ }^{1} \mathrm{H}$ NMR (400.13 MHz, DMSO-d $\left.d_{6}\right) \delta / \mathrm{ppm} 10.38$ (s, 1H, $\mathrm{N} 4 \mathrm{H}), 8.13$ (s, 1H, N5H), 8.06 (s, 1H, H2), 6.42 (s, 1H, $\mathrm{N} 5 \mathrm{H}) 5.13$ (s, 2H, H4), $2.38\left(\mathrm{~s}, 3 \mathrm{H}, \mathrm{C}_{1 C H}\right), 2.01$ (s, 3H, $\left.\mathrm{C} \mathrm{CH}_{3}\right) ;{ }^{13} \mathrm{C}\left\{{ }^{1} \mathrm{H}\right\}$ NMR (100.61 MHz, DMSO- $\left.d_{6}\right) \delta / \mathrm{ppm}$ 178.8 (C6), 151.8 (C1), 147.4 (C5), 138.5 (C3), 132.5 (C2), $\left.50.0(\mathrm{C} 4), 15.1\left(\mathrm{C} 5 \underline{C H}_{3}\right)\right), 13.6\left(\mathrm{C} \underline{\mathrm{CH}}_{3}\right)$; yield $84 \%$.

(E)-N-Methyl-2-(1-(2-methyl-5-nitro-1 H-imidazol-1-yl) propan-2-ylidene)hydrazinecarbothioamidetrichloro] bismuth(III)[Bi(HL4) $\left.\mathrm{Cl}_{3}\right](6)$

Yellow solid; anal. calc. for $\mathrm{C}_{9} \mathrm{H}_{14} \mathrm{BiCl}_{3} \mathrm{~N}_{6} \mathrm{O}_{2} \mathrm{~S}$ 
(FW: $585.65 \mathrm{~g} \mathrm{~mol}^{-1}$ ): $\mathrm{C}, 18.46 ; \mathrm{H}, 2.41 ; \mathrm{N}, 14.35$; found: $\mathrm{C}, 18.47 ; \mathrm{H}, 2.49 ; \mathrm{N}, 14.63$; melting point: 141.0-142.2 ${ }^{\circ} \mathrm{C}$; molar conductivity $\left(1.0 \times 10^{-3} \mathrm{~mol} \mathrm{~L}^{-1}\right.$ DMSO) $5.72 \mathrm{~cm}^{2} \Omega^{-1} \mathrm{~mol}^{-1}$; IR (KBr) $v / \mathrm{cm}^{-1} 3342$ ( v N4-H), $774(v \mathrm{C}=\mathrm{S}), 1540(v \mathrm{C} 5=\mathrm{N}), 1486 / 1368$ $\left(v_{\text {ass }} / v_{\mathrm{s}} \mathrm{NO}_{2}\right) ;{ }^{1} \mathrm{H}$ NMR $\left(400.13 \mathrm{MHz}, \mathrm{DMSO}-d_{6}\right)$ $\delta / \mathrm{ppm} 10.32$ (s, 1H, N4H), 8.08 (s, 1H, H2), 7.24 (s, 1H, N5H), 5.12 (s, 2H, H4), 2.89 (d, 3H, H7, J 4.08 Hz)

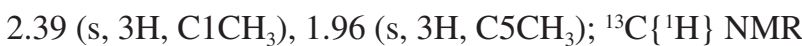
$\left(100.61 \mathrm{MHz}, \mathrm{DMSO}-d_{6}\right) \delta / \mathrm{ppm} 178.8(\mathrm{C} 6), 151.8(\mathrm{C} 1)$, 147.0 (C5), 138.5 (C3), 132.7 (C2), 50.2 (C4), 30.6 (C7), $\left.14.8\left(\mathrm{C}^{2} \underline{\mathrm{C}}_{3}\right)\right), 13.8\left(\mathrm{C}^{2} \underline{\mathrm{CH}}_{3}\right)$; yield $66 \%$. Several attempts to grow crystals of complexes (1-6) were unsuccessful.

\section{Antimicrobial activity}

\section{Yeast cell cultures}

Candida albicans (ATCC 18804), Candida dubliniensis (clinical isolate 28), Candida lusitaniae (CBS 6936) and Candida glabrata (ATCC 90030) strains were obtained from American Type Culture Collection (ATCC, USA) and from Centraalbureau voor Schimmelcultures (CBS, Netherlands).

The tests with Candida strains were performed in Sabouraud dextrose (SBD) medium. The Candida strains were stored and sub-cultured for testing in the same medium and incubated at $37^{\circ} \mathrm{C}$ for $24 \mathrm{~h}$. Dilutions were carried out to achieve the required final concentration of $1-2 \times 10^{8} \mathrm{CFU} \mathrm{mL}^{-1}$ (CFU is defined as colony forming units) determined by a spectrophotometric method. The cell density was determined taking into consideration the turbidity of the suspension, on a spectrophotometer, according to the guidelines of the National Committee for Clinical Laboratory Standards (NCCLS) for yeasts (M27-A3).

Antifungal activity - In vitro susceptibility testing by the microdilution method

The antifungal activity of the compounds was evaluated in final concentrations ranging from 250 to $0.12 \mathrm{mg} \mathrm{mL}^{-1}$ in microdilution plates with 96-wells. The compounds under study and the negative controls were prepared as $12.5 \mathrm{mg} \mathrm{mL}^{-1}$ stock solutions in DMSO. Subsequently, the stock solutions were diluted in culture medium containing Tween $80(0.5 \% \mathrm{v} / \mathrm{v})$ in order to obtain $500 \mu \mathrm{g} \mathrm{mL}^{-1}$ solutions. Further dilutions of each compound were performed. The wells of the microdilution plates were filled with $100 \mu \mathrm{L}$ of solutions with decreasing concentrations of the compounds in culture medium. Then, $100 \mu \mathrm{L}$ of the solution containing the standardized inocula were added and the microplates were incubated at $37{ }^{\circ} \mathrm{C}$ for $24 \mathrm{~h}$. Three control tests were prepared, as follows: $(i)$ with the microorganisms in culture medium alone (positive control), (ii) with the compounds in culture medium without microorganisms and (iii) with only the culture medium. The experiments were performed in triplicate and the absorbances were determined on an ELISA (enzyme-linked immunosorbent assay) tray reader (Thermoplate, Brazil) at a fixed wavelength of $490 \mathrm{~nm}$. Minimum inhibitory concentrations (MICs) were calculated based on the quantity of the microorganism present after the experiments, i.e., the lowest concentration of compounds that resulted in inhibition of $50 \%$ of growth $\left(\mathrm{IC}_{50}\right)$ compared with the positive control test. The results were processed by OriginPro $9.0^{\circledR}$ software $^{15}$ using dose-response curves. For comparison, $\mathrm{IC}_{50}$ values were converted to $\mu \mathrm{M}$.

\section{Antibacterial activity}

In vitro susceptibility to the compounds under study was evaluated according to Clinical \& Laboratory Standards Institute (CLSI). ${ }^{16}$ Six reference strains of Gram-negative anaerobic bacteria were tested: Bacteroides fragilis (ATCC 25285), Bacteroides thetaiotaomicron (ATCC23745), Bacteroides vulgatus (ATCC 8482), Bacteroides ovatus (ATCC 8483), Parabacteroides distasonis (ATCC 1945) and Fusubacterium nucleatum (ATCC 25586).

In order to evaluate the minimum inhibitory concentration of each compound, bacterial strains were cultured in Brucella Agar supplemented with hemin $\left(5 \mu \mathrm{g} \mathrm{mL} \mathrm{mL}^{-1}\right)$, vitamin $\mathrm{K} 1\left(1 \mu \mathrm{g} \mathrm{mL} \mathrm{m}^{-1}\right)$ and horse blood $(5 \% \mathrm{v} / \mathrm{v})(\mathrm{BA}-\mathrm{S})$, at $37{ }^{\circ} \mathrm{C}$ for $48 \mathrm{~h}$ in an anaerobic chamber $\left(85 \% \mathrm{~N}_{2}, 10 \% \mathrm{H}_{2}\right.$ and $\left.5 \% \mathrm{CO}_{2}\right)$. The inoculum was prepared in sterile saline solution $0.9 \% \mathrm{~m} / \mathrm{v}$ and standardized to obtain visual turbidity comparable to that of the standard 0.5 of the McFarland scale, which provides

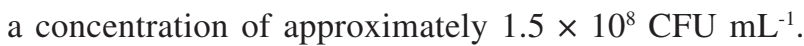
A 1:10 dilution of the inoculum was prepared in sterile saline solution $0.9 \% \mathrm{~m} / \mathrm{v}$, resulting in a concentration of approximately $1.5 \times 10^{7} \mathrm{CFU} \mathrm{mL} \mathrm{m}^{-1}$. The adjusted suspensions were used in the final inoculation up to $30 \mathrm{~min}$ after preparation.

The compounds were tested for determination of minimum inhibitory concentration (MIC) by the agar dilution method. Briefly, the technique consisted of adding $4.0 \mathrm{~mL}$ of working solution of the compounds containing nine different concentrations (ranging from 320 to $1.25 \mu \mathrm{g} \mathrm{mL}^{-1}$ ) in flasks containing $36 \mathrm{~mL}$ of the culture medium followed by plating. In the preparation of the working solutions of the compounds, DMSO was used as the solvent and sterile distilled water as the diluent, so that the final concentration of DMSO was less than $0.5 \%$ in all tests. Inoculation was performed by adding, approximately $10^{5} \mathrm{CFU}$ per spot of each bacterial strain using the Steers 
replicator and subsequent anaerobic incubation at $37^{\circ} \mathrm{C}$ for $48 \mathrm{~h}$.

The minimum inhibitory concentration (MIC) was expressed as the lowest concentration that resulted in visual inhibition of the microorganism growth compared with the growth in the culture medium free of the tested compound (positive control). In addition, incubation in the absence of inoculum was performed to confirm the sterility of the culture medium (negative control) as well as the control to assure the non-interference of DMSO in cell viability. The tests were performed in duplicate with absolute agreement of the results and the MIC values were expressed in $\mu \mathrm{M}$.

\section{Results and Discussion}

Formation of silver(I) complexes (1-4) and of bismuth(III) complexes (5-6)

Microanalyses and molar conductivity data were compatible with the formation of $\left[\mathrm{Ag}(\mathrm{HL}) \mathrm{NO}_{3}\right]$ (1-4) and $\left[\mathrm{Bi}(\mathrm{HL}) \mathrm{Cl}_{3}\right]$ (5-6) complexes, in which one neutral thiosemicarbazone or hydrazone ligand is attached to the metal center together with a nitrate ion (1-4) or three chloride ions (5-6). The relatively high values of molar conductivities of 1-4 suggest nitrate release in solution, as previously observed for silver(I) complexes with 2-acetylpyridine- and 2-benzoylpyridine-derived hydrazones. ${ }^{5,17}$

\section{Spectroscopic characterization}

\section{Infrared spectra}

The $v(C 5=N)$ absorption, observed at $1526-1532 \mathrm{~cm}^{-1}$ in the infrared spectra of the free bases, shifts to $1524-1560 \mathrm{~cm}^{-1}$ in those of complexes (1-6), in accordance with coordination through the imine carbon. The $\mathrm{v}(\mathrm{C}=\mathrm{O})$ absorption at $1678 \mathrm{~cm}^{-1}$ in the spectrum of HL1 does not shift in complex (1), while this absorption shifts from $1670 \mathrm{~cm}^{-1}$ in HL2 to $1654 \mathrm{~cm}^{-1}$ in complex (2). The vibrations attributed to $v(\mathrm{C}=\mathrm{S})$, observed at 804 and $786 \mathrm{~cm}^{-1}$ in HL3 and HL4, respectively, shift to 794 and $788 \mathrm{~cm}^{-1}$ in complexes (3) and (4), respectively, and to 742 and $774 \mathrm{~cm}^{-1}$ in (5) and (6), respectively, suggesting coordination through the sulfur. ${ }^{14}$ In addition, an absorption at $1380-1388 \mathrm{~cm}^{-1}$ was observed in the spectra of complexes (1-4), corresponding to the presence of nitrate in the metal coordination sphere. ${ }^{18}$

\section{NMR spectra}

NMR spectra were recorded in DMSO- $d_{6}$. The ${ }^{1} \mathrm{H}$ resonances were doubtless assigned on the basis of chemical shifts, multiplicities and by using $2 \mathrm{D}$ homonuclear ${ }^{1} \mathrm{H}-{ }^{1} \mathrm{H}$ correlation spectroscopy (COSY). The carbon type (C, $\mathrm{CH}$ ) was determined by using distortionless enhancement by polarization transfer (DEPT-135) experiments and the assignments were made by $2 \mathrm{D}$ heteronuclear multiple quantum coherence (HMQC) experiments.

In the ${ }^{1} \mathrm{H}$ NMR spectra of the free thiosemicarbazones and hydrazones a signal corresponding to N4-H was observed at $\delta 10.31-10.69$. This signal was found at $\delta 10.32-10.87$ in complexes (1-6). The signal of N5-H, observed at $\delta 6.41$ and $\delta 8.16$ in HL3 shifts to $\delta 7.32$ and $\delta 8.82$ in complex (3) and to $\delta 6.42$ and $\delta 8.13$ in complex (5). This signal, observed at $\delta 7.24$ in HL4, shifts to $\delta 8.15$ in complex (4) and to $\delta$ 7.24 in complex (6). In the ${ }^{13} \mathrm{C}\left\{{ }^{1} \mathrm{H}\right\}$ NMR spectra of the Schiff bases the signal at $\delta 144.9-151.7$ was assigned to carbon C5. This signal was found at $\delta$ 144.8-152.1 in complexes (1-4), suggesting coordination through the iminic nitrogen. The C5 signal was observed at $\delta 147.4$ in complexes (5) and (6). The signal of $\mathrm{C}=\mathrm{O}$ was noticed at $\delta 172.2$ and $\delta 163.1$ for HL1 and HL2, respectively. This signal does not shift upon coordination, suggesting that the carbonyl oxygen is probably feebly attached to the silver center, as previously observed in silver(I) complexes with 2-acetyl- and 2-benzoylpyridine hydrazones. ${ }^{5,17}$ The signals of $\mathrm{C}=\mathrm{S}$ were observed at $\delta 178.9$ for both HL3 and HL4. Upon complexation this signal shifts to $\delta 174.4$ and $\delta 174.3$ in complexes (3) and (4), respectively, and to 178.8 in (5) and (6), indicating coordination through the sulfur. ${ }^{17}$

\section{Electrochemistry studies}

Secnidazole and HL1-HL4 displayed a stable welldefined couple (system Ic/Ia, anodic (Ia) and cathodic (Ic) peak currents) with $\mathrm{Ep}_{\mathrm{Ic}}$ near $-1100 \mathrm{mV}$, corresponding to a monoelectronic transfer process attributed to the formation of a stable nitro radical anion $\left(\mathrm{R}-\mathrm{NO}_{2}{ }^{-}\right)$. The voltammograms also exhibited a second wave near $-2000 \mathrm{mV}$, assigned to the generation of hydroxylamine $(\mathrm{R}-\mathrm{NHOH})$ and, in some cases, an irreversible oxidation near to $-500 \mathrm{mV}$, related to the formation of nitroso (R-NO) species (see equations 1-3). ${ }^{14}$

Peaks Ic and Ia $\mathrm{R}-\mathrm{NO}_{2}+\mathrm{e}^{-} \rightleftharpoons \mathrm{R}-\mathrm{NO}_{2}{ }^{--}$

Peak IIc $\quad \mathrm{R}_{-} \mathrm{NO}_{2}{ }^{--}+3 \mathrm{e}^{-}+4 \mathrm{H}^{+} \rightarrow \mathrm{R}-\mathrm{NHOH}+\mathrm{H}_{2} \mathrm{O}$ (2)

Peak IIIa $\mathrm{R}-\mathrm{NHOH} \rightleftharpoons \mathrm{R}-\mathrm{NO}+2 \mathrm{e}^{-}+2 \mathrm{H}^{+}$

The voltammograms of complexes (1-6) (see Figure 2 and S19, Supplementary Information (SI)) show two quasi-reversible processes which were attributed to the $\mathrm{R}-\mathrm{NO}_{2} / \mathrm{R}-\mathrm{NO}_{2}{ }^{--}$(peaks Ic and Ia). The EpIc values suggest that the formation of $\mathrm{R}-\mathrm{NO}_{2}{ }^{--}$is favored in 
complexes (1-6) in comparison to the Schiff base ligands (Table 1).

In complexes (1-4) an irreversible oxidation process (IVa) in the $770-860 \mathrm{mV}$ range was attributed to the silver(I) $\rightarrow$ silver(II) oxidation and an irreversible process at $375-430 \mathrm{mV}$ range was assigned to the silver $(\mathrm{I}) \rightarrow \operatorname{silver}(0)$ reduction, in accordance with processes reported in the literature for other silver(I) complexes. ${ }^{19}$ In complexes (5-6) the processes (Va) at 206 and $133 \mathrm{mV}$ were attributed to the bismuth(III) $\rightarrow$ bismuth(IV) oxidation.

\section{Antimicrobial activity}

Although the free ligands were inactive, silver(I) complexes (1-4) showed antimicrobial effects against Candida yeast strains (Table 2), being more active than silver nitrate. Some complexes were as active as nystatin against $C$. dubliniensis. Since silver nitrate showed

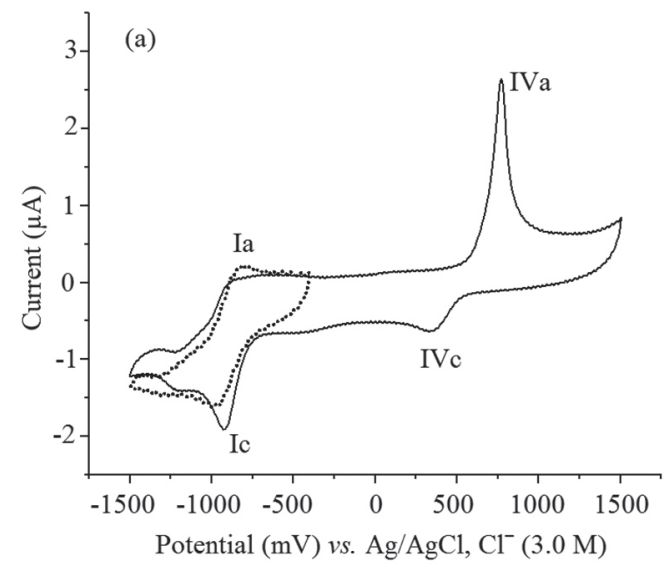

antifungal activity, the observed effects of complexes (1-4) are probably due to the presence of silver(I). Unlike complexes (1-4), complexes (5-6) did not show antifungal effects, corroborating the assumption that the antifungal properties of (1-4) are due to the presence of silver(I). Interestingly, copper(II) complexes with the same ligands did also not show antifungal activity against the Candida strains. ${ }^{14}$ Hence, in the case of the silver(I) complexes (1-4), the antifungal activity is not due to the nitro pharmacophoric group, but it is probably related to the presence of silver(I), the role of coordination being possibly to increase lipophilicity, allowing the metal to cross the fungal cell membrane.

The Schiff base ligands and their silver(I) and bismuth(III) complexes proved to be inactive against Bacillus cereus (ATCC 11778), Listeria monocytogenes (ATCC 15313), Staphylococcus aureus (ATCC 25923) and Streptococcus sanguinis (ATCC 49456) Gram-positive and

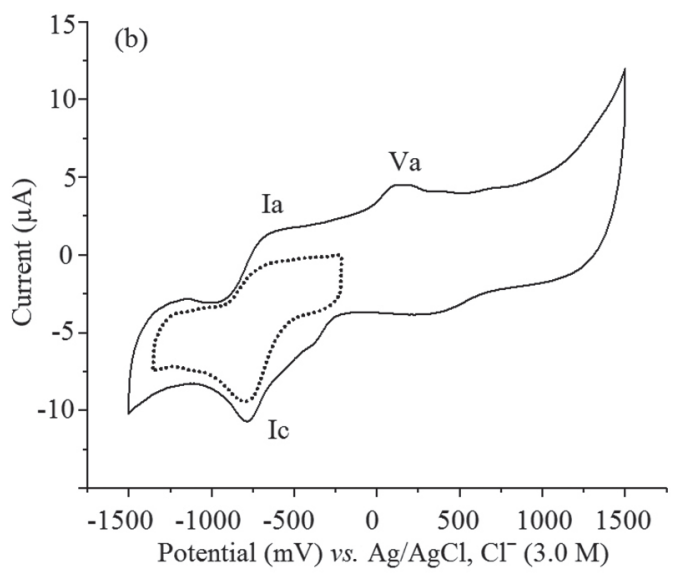

Figure 2. Cyclic voltammogram of (a) complex (1), (b) complex (5) in aprotic media (1 M TBAP in DMF) vs. $\mathrm{Ag} / \mathrm{AgCl}, \mathrm{Cl}^{-}(3.0 \mathrm{M})$; scan rate of $250 \mathrm{mV} \mathrm{s}^{-1}$. Dotted line shows a short sweep with the isolated $\mathrm{RNO}_{2} / \mathrm{R}-\mathrm{NO}_{2}^{--}$couple.

Table 1. Cyclic voltammetry parameters ${ }^{\mathrm{a}}$ corresponding to the $\mathrm{R}-\mathrm{NO}_{2} / \mathrm{R}-\mathrm{NO}_{2}{ }^{--}, \mathrm{Ag}^{\mathrm{I}} / \mathrm{Ag}^{\mathrm{II}}, \mathrm{Ag}^{\mathrm{I}} / \mathrm{Ag}^{0}$ and $\mathrm{Bi}^{\mathrm{III}} / \mathrm{Bi}^{\mathrm{IV}}$ processes $v s . \mathrm{Ag} / \mathrm{AgCl}, \mathrm{Cl}{ }^{-}(3.0 \mathrm{M})$ reference electrode

\begin{tabular}{|c|c|c|c|c|c|c|}
\hline \multirow{2}{*}{ Compound $^{\mathrm{b}}$} & \multicolumn{3}{|c|}{$\mathrm{R}-\mathrm{NO}_{2} / \mathrm{R}-\mathrm{NO}_{2}{ }^{-}$} & \multirow{2}{*}{$\frac{\mathrm{Ag}^{\mathrm{I}} / \mathrm{Ag}^{\mathrm{II}}}{\mathrm{Ep}_{\mathrm{IVa}} / \mathrm{mV}}$} & \multirow{2}{*}{$\frac{\mathrm{Ag}^{\mathrm{I}} / \mathrm{Ag}^{0}}{\mathrm{Ep}_{\mathrm{IVc}} / \mathrm{mV}}$} & \multirow{2}{*}{$\frac{\mathrm{Bi}^{\mathrm{III}} / \mathrm{Bi}^{\mathrm{IV}}}{\mathrm{Ep}_{\mathrm{Va}} / \mathrm{mV}}$} \\
\hline & $\mathrm{Ep}_{\mathrm{Ic}} / \mathrm{mV}$ & $\Delta \mathrm{Ep} / \mathrm{mV}$ & $\mathrm{Ip}_{\mathrm{Ia}} / \mathrm{Ip}_{\mathrm{Ic}}$ & & & \\
\hline HL1 & -1101 & 122 & 0.87 & - & - & - \\
\hline$\left[\mathrm{Ag}(\mathrm{HL} 1) \mathrm{NO}_{3}\right](\mathbf{1})$ & -928 & 58 & 0.80 & 770 & 375 & - \\
\hline HL2 & -1115 & 78 & 0.82 & - & - & - \\
\hline$\left[\mathrm{Ag}(\mathrm{HL} 2) \mathrm{NO}_{3}\right](\mathbf{2})$ & -873 & 34 & 0.54 & 860 & 430 & - \\
\hline HL3 & -1120 & 83 & 0.83 & - & - & - \\
\hline$\left[\mathrm{Ag}(\mathrm{HL} 3) \mathrm{NO}_{3}\right](\mathbf{3})$ & -831 & 44 & 0.45 & 849 & 401 & - \\
\hline$\left[\mathrm{Bi}(\mathrm{HL} 3) \mathrm{Cl}_{3}\right](\mathbf{5})$ & -843 & 68 & 0.37 & - & - & 206 \\
\hline HL4 & -1125 & 141 & 0.92 & - & - & - \\
\hline$\left[\mathrm{Ag}(\mathrm{HL} 4) \mathrm{NO}_{3}\right](\mathbf{4})$ & -826 & 58 & 0.62 & 785 & 390 & - \\
\hline$\left[\mathrm{Bi}(\mathrm{HL} 4) \mathrm{Cl}_{3}\right](\mathbf{6})$ & -742 & 88 & 0.37 & - & - & 133 \\
\hline
\end{tabular}

${ }^{\mathrm{a}} \mathrm{Scan}$ rate of $250 \mathrm{mV} \mathrm{s}^{-1}$; ${ }^{\mathrm{b}}$ compounds at $1 \mathrm{mM}$ dissolved in DMF using $1 \mathrm{M}$ TBAP as supporting electrolyte, anodic (Ia) and cathodic (Ic) peak currents, and the corresponding potential (Ep). 
Table 2. Antifungal activity ( $\mathrm{IC}_{50}$ ) of compounds against Candida albicans (ATCC 18804), Candida dubliniensis (clinical isolate 28), Candida lusitaniae (CBS 6936) and Candida glabrata (ATCC 90030)

\begin{tabular}{|c|c|c|c|c|}
\hline \multirow{2}{*}{ Compound } & \multicolumn{4}{|c|}{$\mathrm{IC}_{50} / \mu \mathrm{M}$} \\
\hline & Candida albicans & Candida dubliniensis & Candida glabrata & Candida lusitaniae \\
\hline HL1 & - & - & - & - \\
\hline$\left[\mathrm{Ag}(\mathrm{HL} 1) \mathrm{NO}_{3}\right](\mathbf{1})$ & $16.43 \pm 1.96$ & $5.29 \pm 0.33$ & $27.20 \pm 2.79$ & $9.57 \pm 0.22$ \\
\hline HL2 & - & - & - & - \\
\hline$\left[\mathrm{Ag}(\mathrm{HL} 2) \mathrm{NO}_{3}\right](\mathbf{2})$ & $>8$ & $8.00 \pm 0.20$ & $28.49 \pm 1.17$ & $8.59 \pm 0.13$ \\
\hline HL3 & - & - & - & - \\
\hline$\left[\mathrm{Ag}(\mathrm{HL} 3) \mathrm{NO}_{3}\right](\mathbf{3})$ & $10.55 \pm 0.42$ & $5.63 \pm 0.23$ & $24.35 \pm 5.18$ & $10.31 \pm 0.21$ \\
\hline HL4 & - & - & - & - \\
\hline$\left[\mathrm{Ag}(\mathrm{HL} 4) \mathrm{NO}_{3}\right](\mathbf{4})$ & $11.50 \pm 0.39$ & $7.88 \pm 0.17$ & $19.39 \pm 0.05$ & $8.59 \pm 0.15$ \\
\hline $\mathrm{AgNO}_{3}$ & $40.33 \pm 1.46$ & $>11$ & $64.24 \pm 2.21$ & $20.79 \pm 1.76$ \\
\hline Miconazole nitrate & $5.84 \pm 2.27$ & $1.58 \pm 0.51$ & $19.50 \pm 4.53$ & $<0.062 \times 10^{-3}$ \\
\hline Nystatin & $4.75 \pm 1.24$ & $4.44 \pm 0.76$ & $1.92 \pm 0.22$ & $5.31 \pm 0.84$ \\
\hline
\end{tabular}

$\mathrm{IC}_{50}$ : half maximal inhibitory concentration.

against Citrobacter freundii (ATCC 8090), Escherichia coli (ATCC 25723), Pseudomonas aeruginosa (ATCC 27853) and Salmonella typhimurium (ATCC 13311) Gram-negative aerobic bacteria.

In contrast, the free ligands and complexes (1-6) exhibited potent antimicrobial effects against the studied anaerobic bacterial strains (Table 3). Except for HL4, upon coordination of the Schiff base ligands to both silver(I) and bismuth(III), the antibacterial activity increased in several cases. While silver nitrate revealed to be inactive, complexes (1-4) proved to be equally or more active than the original ligands and to be as active as metronidazole. Likewise, complex (5) revealed to be more effective than the parent thiosemicarbazone against several bacterial strains. Comparison of the MIC values of complexes (1-6) and of the previously reported copper(II) analogues ${ }^{14}$ shows that the complexes exhibit similar antibacterial effects, which are due to the presence of the nitro pharmacophoric group in the ligands. As already mentioned, upon complexation to copper(II), silver(I) and bismuth(III) reduction of the nitro group is favored, which might in part account for the improved antibacterial effects of the complexes

Table 3. Antibacterial activity (MIC values) of compounds against Bacteroides fragilis (ATCC25285), Bacteroides thetaiotaomicron (ATCC 23745), Bacteroides vulgatus (ATCC 8482), Bacteroides ovatus (ATCC 8483), Parabacteroides distasonis (ATCC 1945) and Fusubacterium nucleatum (ATCC 25586)

\begin{tabular}{|c|c|c|c|c|c|c|}
\hline \multirow{2}{*}{ Compound } & \multicolumn{6}{|c|}{$\mathrm{MIC} / \mu \mathrm{M}$} \\
\hline & B. fragilis & B. thetaiotaomicron & B. vulgatus & B. ovatus & P. distasonis & F. nucleatum \\
\hline HL1 & 29.78 & 7.45 & 3.72 & 3.72 & 7.45 & 8.36 \\
\hline$\left[\mathrm{Ag}(\mathrm{HL} 1) \mathrm{NO}_{3}\right](\mathbf{1})$ & 4.18 & 4.18 & 4.18 & $\leq 2.09$ & 16.72 & 4.18 \\
\hline HL2 & 13.28 & 13.28 & 13.28 & 6.64 & 13.28 & 6.64 \\
\hline$\left[\mathrm{Ag}(\mathrm{HL} 2) \mathrm{NO}_{3}\right](\mathbf{2})$ & 3.32 & 3.32 & 3.32 & 1.66 & 6.64 & 3.32 \\
\hline HL3 & 25.36 & 25.36 & 12.68 & 3.17 & 6.34 & 3.90 \\
\hline$\left[\mathrm{Ag}(\mathrm{HL} 3) \mathrm{NO}_{3}\right](\mathbf{3})$ & 3.90 & 7.80 & 3.90 & 3.90 & 15.60 & 3.90 \\
\hline$\left[\mathrm{Bi}(\mathrm{HL} 3) \mathrm{Cl}_{3}\right](\mathbf{5})$ & 7.80 & 15.61 & 7.80 & 7.80 & 1.95 & 7.80 \\
\hline HL4 & 3.24 & 6.47 & 3.24 & 3.24 & 6.47 & 3.24 \\
\hline$\left[\mathrm{Ag}(\mathrm{HL} 4) \mathrm{NO}_{3}\right](\mathbf{4})$ & 3.70 & 3.70 & 3.70 & 3.70 & $\geq 7.38$ & 3.70 \\
\hline$\left[\mathrm{Bi}(\mathrm{HL} 4) \mathrm{Cl}_{3}\right](\mathbf{6})$ & 3.70 & 7.40 & 3.70 & 3.70 & $\geq 7.40$ & 3.70 \\
\hline $\mathrm{AgNO}_{3}$ & $\geq 187.77$ & $\geq 187.77$ & $\geq 187.77$ & 187.77 & 94.19 & 187.77 \\
\hline $\mathrm{BiCl}_{3}$ & ND & ND & ND & ND & ND & ND \\
\hline Metronidazole & 3.17 & 3.17 & 3.17 & 3.17 & 6.34 & 1.46 \\
\hline
\end{tabular}

ND: not determined since $\mathrm{BiCl}_{3}$ forms insoluble hydroxylated species in aqueous media. MIC: minimum inhibitory concentration. 


\section{Conclusions}

Nitroimidazoles are prodrugs that require bioactivation of the nitro group in order to exert their antimicrobial effect. The mechanism of action of these compounds involves reduction of the nitro group generating reactive radical species, mainly the nitro anion radical $\mathrm{R}-\mathrm{NO}_{2}{ }^{-}$ which reacts with cellular components such as DNA or proteins. Under anaerobic conditions, the redox potential of the electron-transport system in microbes is sufficiently negative to reduce the nitro group. However, in the presence of oxygen, the nitro radical anion is rapidly re-oxidized to its parent precursor in a futile cycling, with impairment of the bactericidal effects. ${ }^{12}$

The fact that the Schiff base ligands and their silver(I) and bismuth(III) complexes did not show antimicrobial activity against aerobic bacteria but were highly active against anaerobic strains strongly suggests formation of the $\mathrm{R}-\mathrm{NO}_{2}{ }^{-}-$nitro anion radical under anaerobic conditions and the possible participation of these species in the mode of antibacterial effect of the compounds under study.

The redox potential for the formation of the $\mathrm{R}-\mathrm{NO}_{2}{ }^{-}$ nitro anion radical for the copper(II), ${ }^{14}$ silver(I) and bismuth(III) complexes are more favorable than in the case of the free ligands, which, at least in part, might account for the higher antimicrobial activity of the complexes. Considering the fact that silver(I) and bismuth(III) compounds are already clinically employed as antimicrobial agents and the relatively acceptable toxicity of these compounds, coordination to silver(I) and bismuth(III) might probably constitute better strategies than coordination to copper(II) for the design of new antimicrobial drug candidates to treat infection originated from anaerobic bacteria.

In addition, complexes (1-4) showed antifungal effects, unlike their copper(II) and bismuth(III) congeners, suggesting that the silver(I) complexes exhibit a broader spectrum of action. Since the free Schiff bases and their bismuth(III) and copper(II) complexes do not show antifungal properties, the antifungal activities of complexes (1-4) are probably due to the presence of silver(I).

Increased use of nitro-heterocyclic drugs has resulted in drug resistance to a number of these agents in Bacteroides and other bacterial strains. ${ }^{20}$ In fact, several studies have reported decreased susceptibility among Bacteroides species to nitroimidazole derivatives. Since anaerobes can cause infections at almost all anatomic sites and are an important cause of bloodstream infections, accounting for up to $17 \%$ of positive blood cultures, ${ }^{21}$ investigation on novel antibacterial agents is of utmost relevance.

\section{Supplementary Information}

Supplementary data (infrared, ${ }^{1} \mathrm{H}$ and ${ }^{13} \mathrm{C}$ NMR spectra and the cyclic voltammograms of complexes 1-6) are available free of charge at http://jbcs.sbq.org.br as PDF file.

\section{Acknowledgments}

The authors gratefully acknowledge CNPq, CAPES, FAPEMIG and INCT-INOFAR (proc. CNPq 573.364/2008-6) for financial support and students grants.

\section{References}

1. Beraldo, H.; Gambino, D.; Mini-Rev. Med. Chem. 2004, 4, 31.

2. Thota, S.; Rodrigues, D. A.; Pinheiro, P. S. M.; Lima, L. M.; Fraga, C. A. M.; Barreiro, E.; Bioorg. Med. Chem. Lett. 2018, 28, 2797.

3. da Silva, J. G.; Recio-Despaigne, A. A.; Louro, S. R. W.; Bandeira, C. C.; Souza-Fagundes, E. M.; Beraldo, H.; Eur. J. Med. Chem. 2013, 65, 415.

4. Ferreira, I. P.; Piló, E. D. L.; Recio-Despaigne, A. A.; da Silva, J. G.; Ramos, J. P.; Marques, L. B.; Prazeres, P. H. D. M.; Takahashi, J. A.; Souza-Fagundes, E. M.; Rocha, W.; Beraldo, H.; Bioorg. Med. Chem. 2016, 24, 2988.

5. Santos, A. F.; Ferreira, I. P.; Takahashi, J. A.; Rodrigues, G. L. S.; Pinheiro, C. B.; Teixeira, L. R.; Rocha, W. R.; Beraldo, H.; New J. Chem. 2018, 42, 2125.

6. Cardoso, J. M. S.; Guerreiro, S. I.; Lourenço, A.; Alves, M. M.; Montemor, M. F.; Mira, N. P.; Leitão, J. H.; Carvalho, M. F. N. N.; PLoS One 2017, 12, e0177355.

7. Kalinowska-Lis, U.; Felczak, A.; Chęcińska, L.; Zawadzka, K.; Patyna, E.; Lisowska, K.; Ochockia, J.; Dalton Trans. 2015, 44, 8178.

8. Kalinowska-Lis, U.; Felczak, A.; Chęcińska, L.; Małecka, M.; Lisowska, K.; Ochockia, J.; New J. Chem. 2016, 40, 694.

9. Luqman, A.; Blair, V. L.; Brammananth, R.; Crellin, P. K.; Coppel, R. L.; Andrews, P. C.; Eur. J. Inorg. Chem. 2015, 2015, 4935.

10. Keogan, D. M.; Twamley, B.; Fitzgerald-Hughes, D.; Griffith, D. M.; Dalton Trans. 2016, 45, 11008.

11. Ferraz, K. S. O.; Silva, N. F., Da Silva J. G.; Miranda, L. F.; Romeiro, C. F. D.; Souza-Fagundes, E. M.; Mendes, I. C.; Beraldo H.; Eur. J. Med. Chem. 2012, 53, 98.

12. Nyirjesy, P.; Schwebke, J. R.; Future Microbiol. 2018, 13, 507.

13. Ang, C. W.; Jarrad, A. M.; Cooper, M. A.; Blaskovich, M. A. T.; J. Med. Chem. 2017, 60, 7636.

14. Oliveira, A. A.; Oliveira, A. P. A.; Franco, L. L.; Ferencs, M. O.; Ferreira, J. F. G.; Bachi, S. M. P. S.; Speziali, N. L.; Farias, L. M.; Magalhães, P. P.; Beraldo, H.; Biometals 2018, 31, 571. 
15. OriginPro 9.0; OriginLab Corporation, Northampton, MA, USA, 2012.

16. Clinical and Laboratory Standards Institute (CLSI); Performance Standards for Antimicrobial Susceptibility Testing; Twenty-Fifth Informational Supplement, CLSI document M100-S25; CLSI: Pennsylvania, USA, 2015.

17. Santos, A. F.; Ferreira, I. P.; Pinheiro, C. B.; Santos, V. G.; Lopes, M. T. P.; Teixeira, L. R.; Rocha, W. R.; Rodrigues, G. L. S.; Beraldo, H.; ACS Omega 2018, 3, 7027.
18. Nakamoto, K.; Infrared Spectra of Inorganic and Coordination Compounds; Wiley-Interscience: New York, USA, 1970.

19. Movahedi, E.; Rezvani, A. R.; J. Mol. Struct. 2017, 1139, 407.

20. Townson, S. M.; Boreham, P. F. L.; Upcroft, P.; Upcroft, J. A.; Acta Trop. 1994, 56, 173.

21. Brook, I.; Anaerobe 2010, 16, 183.

Submitted: February 2, 2019

Published online: June 6, 2019 